\title{
Pelestarian Alam sebagai Perwujudan Mandat Pembangunan: Suatu Kajian Etis-Teologis
}

\author{
Kalis Stevanus \\ Sekolah Tinggi Teologi Tawangmangu \\ kalisstevanus91@gmail.com
}

\begin{abstract}
Lately, the attention and awareness of humankind to protect and maintain environmental sustainability are increasing. Environmental damage today is a big problem and is global, which is now an increasingly critical problem. The world is experiencing the danger of an ecological crisis. This article is intended to describe the Church's ethical-theological attitude in addressing environmental issues today is a very crucial issue to consider. Using research that uses qualitative research using descriptive methods based on the Bible and also using library research by analyzing literature both books and journals that discuss environmental issues. Based on ethical-theological studies, it can be concluded that humans are the managers of nature, and preservation of nature is as an implementation of love for others. By understanding this, it is hoped that the Environment, which has been entrusted to humans, needs to be managed wisely, responsibly and productively as possible for the needs and progress of future generations.
\end{abstract}

\begin{abstract}
Abstrak
Akhir-akhir ini perhatian dan kesadaran umat manusia untuk menjaga dan memelihara kelestarian lingkungan hidupnya semakin meningkat. Kerusakan lingkungan hidup dewasa ini merupakan isu besar dan bersifat global (mendunia), yang kini menjadi masalah yang semakin genting. Dunia sedang menghadapi bahaya krisis ekologis. Artikel ini bertujuan untuk memaparkan sikap etis-teologis Gereja dalam menyikapi isu tentang lingkungan hidup dewasa ini menjadi isu yang sangat krusial untuk diperhatikan. Adapun pendekatan penelitian yang penulis gunakan adalah penelitian kualitatif dengan menggunakan metode deskriptif berdasarkan Alkitab dan juga menggunakan penelitian kepustakaan dengan cara menganalis literatur baik buku maupun jurnal yang membahas permasalahan lingkungan hidup. Berdasarkan kajian etis-teologis diperoleh kesimpulan bahwa, manusia adalah pengelola alam, dan pelestarian alam adalah sebagai implementasi kasih kepada sesama. Dengan pemahaman ini, diharapkan lingkungan hidup yang telah dipercayakan kepada manusia, perlu dikelola secara bijak, bertanggungjawab dan seproduktif mungkin untuk kepentingan dan kelangsungan generasi mendatang.
\end{abstract}

Article History

Submit:

04 Maret 2019

Revised:

25 September 2019

Accepted:

05 Oktober 2019

Keywords

(kata kunci): church;

development mandate; ethical-

theological; nature; nature

conservation; alam;

etis-teologis; gereja; mandat

pembangunan; pelestarian alam 


\section{Pendahuluan}

Akhir-akhir ini perhatian dan kesadaran umat manusia terhadap pelestarian lingkungan hidup semakin meningkat. Tidak dapat disanggah bahwa rusaknya alam itu disebabkan oleh ulah manusia sendiri dalam kaitannya dengan pemanfaatan dan pengelolaan sumber-sumber alam yang cenderung bersifat eksploitatif dan destruktif. Seperti diungkapkan oleh Rahmat Mulyana bahwa kondisi lingkungan global dewasa ini semakin memprihatinkan. Hal ini dipicu oleh ulah manusia sendiri yang mengekploitasi sumberdaya alam dan lingkungan tanpa batas cenderung tidak peduli dengan kelangsungan perikehidupan dan kesejahteraan umat manusia serta makhluk lainnya. ${ }^{1}$ Akibatnya sumber alam semakin menipis, kemampuan daya dukung alam berkurang dan mengancam kehidupan manusia sendiri.

Terjadinya kekeringan, tanah-tanah tandus, erosi tanah, hilangnya pohon pelindung, banjir, tanah longsor, pencemaran atmosfir, air, tanah, dan merosotnya kesuburan serta struktur tanah, degradasi tanah (penurunan kualitas tanah), perubahan iklim, semua itu semestinya menyadarkan manusia bahwa alam atau lingkungan hidup di mana mereka tinggal ini terancam kelestariannya. Semua ulah manusia yang hanya mengeksploitasi alam demi keuntungan (ekonomis) semata, tanpa memerdulikan kesehatan alam ciptaan dan kelestarian serta keberlangsungnya untuk jangka panjang di masa depan, akan berakibat negatif bahkan bisa fatal, yaitu merusak tatanan ekosistem. Alam menjadi tidak ramah dan bersahabat dengan manusia. Alam tidak menjadi tempat yang memberikan kenyamanan dan ketentraman untuk manusia menyelenggarakan hidup.

Norman L. Geisler mengatakan bahwa permasalahan pemanasan global merupakan masalah besar yang dihadapi bukan hanya bangsa, tapi telah mendunia. ${ }^{2}$ Hal senada diungkapkan oleh Glen H. Stassen dan David P. Gushee, "kini kita sedang menghadapi ancaman global terhadap kapasitas alam untuk memproduksi bagi umat manusia dan untuk meregenerasi dirinya sendiri. Bumi kita tidak lagi dapat dengan mudah memulihkan dirinya...tetapi semakin lemah dan merosot kondisinya, seperti seorang yang sedang sekarat."3 Merawat alam, lingkungan hidup berarti juga menyelamatkan manusia. Sebaliknya, mengeksploitasi alam, sumber daya ada tanpa memedulikan kelestarian, kesehatan alam ciptaan dan kelangsungannya untuk jangka panjang sama artinya menghancurkan manusia. Hal ini seperti yang diungkapkan oleh John Stott "Jika kita menghabiskan semua sumber daya yang ada, maka kita menghancurkan manusia."4

Badan Pertanggungjawaban Sosial dari Gereja Anglikan di Inggris mengatakan bahwa merusak bumi bukanlah sekadar sebuah pertimbangan yang keliru, atau kesalahan biasa, melainkan sebuah penghujatan dan merupakan suatu dosa melawan Allah dan kemanusiaan. ${ }^{5}$ Jadi, Gereja memiliki tanggung jawab juga untuk mengajar dan mendidik anggotanya sadar lingkungan, yaitu untuk mengusahakan dan memelihara kelestarian lingkungan hidup di sekitarnya. Sesuai ajaran Alkitab di Kejadian 1: 10-12 agar semua makhluk hidup berada

\footnotetext{
${ }^{1}$ Rachmat Mulyana, "Penanaman Etika Lingkungan Melalui Sekolah Perduli Dan Berbudaya Lingkungan," Jurnal Tabularasa PPS Unimed 6, no. 2 (2009): 175-180.

${ }^{2}$ Norman L. Geisler, Etika Kristen: Pilihan Dan Isu (Malang: SAAT, 2010), 373.

${ }^{3}$ Glen H. Stassen and David P.Gushee, Etika Kerajaan (Surabaya: Momentum, 2008), 560-561.

${ }^{4}$ John Stott, Isu-Isu Global (Jakarta: Yayasan Komunikasi Bina Kasih, 2015), 150.

${ }^{5}$ Ibid, 155.
} 
dalam relasi yang sifatnya mutualism, yaitu relasi saling bergantung dan membutuhkan. Sehubungan dengan hal tersebut, penanaman kepedulian terhadap kelestarian sumberdaya alam dan lingkungan di sekitranya perlu dilakukan sejak dini agar terbentuk rasa memiliki, menghargai dan memelihara sumberdaya alam dengan bijaksana. Manusia dituntut untuk menjaga dan melindungi alam beserta segala isinya.

Indonesia termasuk negara yang mana masalah lingkungan hidup sudah sangat memprihatinkan, hal ini dapat dilihat baik secara langsung maupun dari media massa. Banyak kasus pencemaran lingkungan maupun illegal logging yang menimbulkan dampak kerusakan yang memprihatinkan bagi lingkungan. ${ }^{6}$ Datauk Tjumano menguraikan berdasarkan Data Kementerian Lingkungan Hidup dan Kehutanan, Indonesia memproduksi sampah hingga 65 juta ton pada 2016, dan meningkat menjadi 67 ton pada 2017. Sementara itu, data Pusat Oceanografi LIPI menunjukkan, sekitar 35,15\% terumbu karang di Indonesia dalam kondisi tidak baik dan hanya 6,39\% dalam kondisi yang sangat baik. Pemanasan global dipicu karena pembakaran batu bara yang mencapai jumlah emisinya per tahun yaitu 9 miliar ton Co2; Adanya konversi lahan dan perusakan hutan dengan jumlah emisi mencapai 2,53 miliar ton Co2e; dan aktivitas dan pemakaian energy, pertanian dan limbah dengan emisi mencapai 451 juta ton Co2. Juga diperoleh data Korlantas Mabes Polri menyebutkan jumlah kendaraan yang terdaftar sampai 3 Januari 2017 mencapai 102.328.629 kendaraan. Kondisi ini menimbulkan munculnya masalah pencemaran udara. Data kematian akibat polusi udara mencapai lebih dari 165.000 orang. Sedangkan, data WHO di tahun 2017 menyebutkan, Jakarta dan Bandung masuk daftar sebagai 10 besar kota dengan pencemaran udara terburuk di Asia Tenggara. Tingkat polusi udara Jakarta sangat mengkhawatirkan yaitu berada pada level 4,5 kali dari ambang batas yang ditetapkan WHO, dan tiga kali lebih besar dari standar yang ditetapkan pemerintah Indonesia. Sedangkan, berdasarkan data Kementerian Lingkungan Hidup dan Kehutanan, total luas hutan Indonesia saat ini mencapai 124 juta hektar. Sejak 2010 sampai 2017, Indonesia kehilangan luas hutannya hingga lebih dari 684.000 hektar per tahunnya. ${ }^{7}$

Melihat gentingnya kondisi ekologi seperti yang dideskripsikan di atas, lalu, apa yang menjadi tanggung jawab Gereja; apa kontribusi yang dapat diberikan terhadap permasalahan terjadinya kerusakan alam, lingkungan hidup yang berdampak pada pemanasan global? Jelas bahwa ancaman pemanasan global bukan hanya pada "alam" saja, tetapi pada seluruh ciptaan, di mana gereja merupakan bagian di dalamnya. Gereja memperoleh panggilan dan harus menjalankan panggilan tersebut, yaitu mengemban mandat kultural atau mandat pembangunan untuk memelihara ciptaan bagi kesejahteraan kehidupan umat manusia. Kenyataan ini telah mendorong diadakannya penelitian terkait sikap etis-teologis gereja terhadap kerusakan alam, karena hal tersebut merupakan tanggung jawab bersama semua umat manusia.

\section{Mandat Gereja}

Gereja mengemban mandat yang ganda dari Allah, yaitu mandat Penginjilan, dan mandat budaya. Mandat Penginjilan ini sifatnya khusus dan eksklusif, artinya hanya diperuntukan

\footnotetext{
${ }^{6}$ Januari Siregar and Muaz Zul, "Penegakan Hukum Dalam Tindak Pidana Lingkungan Hidup Di Indonesia," Mercatoria 8, no. 2 (2015): 107-131.

${ }^{7}$ Datauk Tjumano, "Kerusakan Lingkungan Hidup Di Indonesia," last modified 2019, accessed September 26, 2019, https://jurnalintelijen.net/2018/07/03/kerusakan-lingkungan-hidup-di-indonesia .
} 
bagi Gereja saja untuk mewartakan kabar keselamatan dalam Kristus melalui pemberitaan Injil. Tidak ada keselamatan di luar Kristus. Keyakinan ini bersifat final dan absolut. Dengan keyakinan tersebut, maka Penginjilan tidak akan pernah berakhir sampai kedatangan Kristus yang kedua kali nanti. ${ }^{8}$ Mandat Penginjilan ini seperti tertulis di Matius 28:19-20; Markus 16:15-16; Lukas 24:47; Yohanes 20:21 dan Kisah Para Rasul 1:8. Setelah Yesus menang atas kuasa maut (bangkit dari kematian), sebelum naik ke surga, Dia mengutus (memberi mandat) pada Gereja untuk memberitakan Injil. Gereja harus menaati perintah/mandat Penginjilan (Amanat Agung) tersebut untuk memberitakan Injil Yesus Kristus kepada segala suku bangsa. ${ }^{9}$ Namun, itu bukanlah sebagai satu-satunya perintah yang Tuhan Yesus berikan kepada gereja-Nya. Tuhan Yesus memerintahkan manusia untuk saling mengasihi. Injil Sinoptik mencatat, bahwa Tuhan Yesus mengutip Perjanjian Lama. Imamat 19:18,"Kasihilah sesamamu manusia seperti dirimu sendiri" (band. Mat.22:39; Mrk.12:31; Luk.10: 27). ${ }^{10}$ Dengan kata lain, Gereja sebagai institusi maupun orang Kristen secara individual perlu turut serta berpartisipasi untuk menjaga, memiliki dan menghargai serta memelihara kelestarian lingkungan hidup, dan itu merupakan salah satu contoh konkret wujud mengasihi sesamanya.

Mandat Penginjilan ini memiliki satu tujuan, yaitu soteriologis-adalah untuk menunjukkan jalan keselamatan (Yoh.3:16). ${ }^{11}$ Allah telah memercayakan kepada Gereja-Nya, para pendosa yang telah ditebus ini, tanggung jawab untuk mengerjakan maksud Allah dalam sejarah, yaitu penyelamatan manusia melalui pemberitaan Injil. Yesus Kristus berkata, "Waktunya telah genap; Kerajaan Allah sudah dekat. Bertobatlah dan percayalah kepada Injil!" (Mrk. 1:15). Sejak Pentakosta, Roh Kudus dicurahkan, maksud penyelamatan Allah dalam sejarah sedang diwujudkan melalui Gereja-Nya. Paulus berkata, "Sebab Allah mendamaikan dunia dengan diri-Nya oleh Kristus dengan tidak memperhitungkan pelanggaran mereka. Ia telah mempercayakan berita pendamaian itu kepada kami" (2 Kor.5:19).

Sedangkan mandat budaya adalah bersifat umum, yakni merupakan tanggung jawab sosial semua orang tanpa kecuali termasuk orang Kristen di dalamnya. Mandat budaya ini telah diberikan oleh Allah kepada Adam dan Hawa sejak di taman Eden. Allah memberi perintah kepada manusia untuk menjaga dan memelihara kelestarian ciptaan-Nya. Hal ini juga demi terpeliharanya kelangsungan hidup manusia itu sendiri dan keturunannya di masa mendatang.

Gereja mempunyai tanggung jawab etis yang universal terhadap ciptaan Allah, yaitu alam (ekologi). Menurut Yuono, di dalam ekologi, diyakini bahwa sistem alam (ekosistem) dan sistem sosial saling berhubungan. Manusia berada dalam sistem sosial (yang di dalamnya mencakup nilai, cara berpikir, paradigma, pengetahuan, ideologi, dan lain sebagainya) dan juga berada dalam ekosistem (yang terdiri dari air, tanah, udara, flora, fauna, alam, dan lain

\footnotetext{
${ }^{8}$ Kalis Stevanus, Benarkah Injil Untuk Semua Orang? (Yogyakarta: Diandra Kreatif, 2017), 23.

${ }^{9}$ Susanto Dwiraharjo, "Kajian Eksegetikal Amanat Agung Menurut Matius 28 : 18-20," Jurnal Teologi Gracia Deo 1, no. 2 (2019): 56-73, http://sttbaptisjkt.ac.id/e-journal/index.php/graciadeo.

${ }^{10}$ Kalis Stevanus, "Mengimplementasikan Pelayanan Yesus Dalam Konteks Misi Masa Kini Menurut Injil Sinoptik" Fidei: Jurnal Teologi Sistematika dan Praktika, Vol. 1, No.2 Desember 2018: 294

${ }^{11}$ Sedangkan menurut Arie de Kuiper yang tercatat di buku klasiknya Missiologia (Jakarta: BPK Gunung Mulia, 2013), yang dikutip Kalis Stevanus di bukunya Lihatlah Sang Juruselamat Dunia (Yogyakarta: Diandra Kreatif, 2018), pada halaman 87, Kuiper menyatakan bahwa "tujuan soteriologis" ini merupakan salah satu motif saja di dalam pelaksanaan Penginjilan.
} 
sebagainya). Kedua sistem ini saling berhubungan dan saling mempengaruhi. ${ }^{12}$ Hal ini terbukti, dalam kehidupannya manusia bergantung dengan alam. Segala kehidupan mahkluk yang ada di bumi saling ketergantungan satu sama lain. Segala sesuatu di dunia ini erat hubungannya satu sama lain. Antara manusia dengan manusia, antara manusia dengan hewan, antara manusia dengan tumbuh-tumbuhan dan bahkan antara manusia dengan benda-benda mati sekalipun. Begitu pula antara hewan dengan hewan, antara hewan dengan manusia, dan antara hewan dengan tumbuh-tumbuhan, dan antara hewan dengan benda-benda mati disekelilingnya. Begitu pula antara tumbuh-tumbuhan dengan tumbuh-tumbuhan, antara tumbuh-tumbuhan dengan manusia, dan juga antara tumbuh-tumbuhan dengan hewan, dan antara tumbuh-tumbuhan dengan benda mati disekelingnya. ${ }^{13}$ Ditandaskan lagi oleh Keraf, bahwa manusia tidak hanya dipandang sebagai makhluk sosial. Manusia pertama-tama harus dipahami sebagai makhluk biologis, makhluk ekologis di mana manusia hanya bisa hidup dan berkembang sebagai manusia utuh dan penuh, tidak hanya dalam komunitas sosial, tetapi juga dalam komunitas ekologis, yaitu makhluk yang kehidupannya tergantung dari dan terkait erat dengan semua kehidupan lain di alam semesta. Tanpa alam, tanpa makhluk hidup lain, menurut Keraf, manusia tidak akan bertahan hidup, karena manusia hanya merupaklan salah satu entitas di alam semesta. ${ }^{14}$ Dengan kata lain, kewajiban dan tanggung jawab manusia tidak lagi dibatasi terhadap sesama manusia. Manusia juga dituntut memiliki kewajiban dan tanggung ajwab terhadap semua kehidupan di alam semesta.

Robert Borrong menyatakan di dalam bukunya "Etika Bumi Baru" bahwa manusia adalah gambar Allah dalam pengertian menjadi wakil dan tanda kehadiran serta pemerintahan Allah di atas alam, adalah tanda atau 'gambar' dari kedaulatan Allah atas semesta. Karena itu, tugas penguasaan 'menaklukan' yang dilakukan manusia sejatinya memiliki sifat penatalayanan. ${ }^{15}$ Seharusnya Kejadian 1:10-12 dipahami dan dijadikan dasar dari penatalayanan (stewardship) manusia dalam alam semesta, yaitu semua makluk hidup berada dalam relasi saling bergantung dan saling membutuhkan. Dengan demikian dapat mencegah praktek keliru manusia terhadap alam yang dapat berakibat fatal bagi seluruh kehidupan ciptaan.

Allah menciptakan alam sesuai dengan maksud dan fungsinya masing-masing dalam hubungan harmonis dan saling memengaruhi satu dengan yang lain demi kelangsungan hidup dan kesejahteraan umat manusia. Mandat ini merupakan mandat kepada manusia sebagai masyarakat (apa pun agamanya), untuk menjadikan bumi ini menjadi tempat yang baik untuk dihuni. Jelas bahwa mandat untuk menjaga dan melestarikan alam-lingkungan hidup ini bukan saja untuk orang Kristen, tetapi juga untuk semua umat manusia. Semua manusia bertanggung jawab untuk ikut memelihara lingkungan hidup dengan bijaksana. Sebagaimana tertulis di dalam Kejadian 1:28, 31; 2:15: Allah menciptakan manusia dengan tujuan salah satunya agar menghuni; memenuhi; menguasai; memelihara alam semesta sebagai tempat

\footnotetext{
${ }^{12}$ Yusup Rogo Yuono, "Melawan Etika Lingkungan Antroposentris Melalui Interpretasi Teologi Penciptaan Sebagai Landasan Bagi Pengelolaan-Pelestarian Lingkungan” Fidei: Jurnal Teologi Sistematika dan Praktika, Vol.2, No.1, Juli 2019: 195

${ }^{13}$ Ketut Meta, "Perspektif Historis Dan Perbandingan Pengaturan Masalah Lingkungan Hidup Di Indonesia" Jurnal Cakrawala Hukum, Vol.6, No.1 Juni 2015:168

${ }^{14}$ A. Sonny Keraf, Etika Lingkungan Hidup (Jakarta: PT Kompas Media, 2010), 5

${ }^{15}$ Robert Borrong "Etika Bumi Baru” (Jakarta: BPK Gunung Mulia, 2003), 182
} 
tinggal yang lestari. Perlu dipahami bahwa kata "menguasai" di sini bukan berarti ijin untuk mengeksploitasi kekayaan alam demi kesenangan pribadi atau kelompok tanpa memerdulikan kelangsungan hidup (kelestariannya) seterusnya demi keturunan umat manusia (sosial). Alam telah diserahkan pengelolaannya kepada manusia untuk digunakan dan dimanfaatkan demi kehidupan dan kesejahteraan manusia. Manusialah yang bertanggungjawab atas kelestarian alam ini. Seperti dikatakan oleh Yuono, ${ }^{16}$ bahwa manusialah yang memegang peranan yang sangat menentukan bagi kelestarian atau keberlangsungan kehidupan di sekitarnya.

Krisis ekologi telah terjadi dan menjadi persoalan dunia di mana orang Kristen dituntut keterlibatannya karena hal itu berkaitan dengan dosa manusia. Tidak dapat dipungkiri ada relasi antara krisis ekologi dan dosa manusia. Perusakan alam, lingkungan hidup disebabkan oleh kerakusan manusia dan karena dosa manusia. Kerakusan manusia dengan mengeksploitasi alam tanpa memedulikan kelestarian dan keberlangsungannya di masa depan seperti penanaman berlebihan dan pengerukan berlebihan adalah bentuk ketidaksetiaan utama manusia kepada Allah Sang Pemilik. Stephen Tong menyatakan dengan bahwa dosa tidak berhenti sebagai peristiwa saja, tetapi justru menjadi perusak yang berkelanjutan dalam diri orang berdosa dan pengganggu segenap tatanan kosmis. Dosa itu menghancurkan hubunganhubungan, baik secara pribadi maupun kosmis. Dosa menghancurkan hubungan manusia dengan alam, manusia dengan manusia, terlebih lagi manusia dengan Allah Sang Pencipta. ${ }^{17}$ Itulah akibat dan dampak dari dosa.

Benar apa yang dikatakan oleh Robert P. Borrong bahwa dari perspektif iman Kristen, perlakuan destruktif-eksploitatif manusia terhadap lingkungan bersumber dari kegagalan manusia memenuhi panggilannya karena manusia jatuh ke dalam dosa. Dosa itu yang telah menyebabkan pencemaran atau polusi moral dan spiritual. Sebagai akibatnya, manusia cenderung bertindak destruktif, termasuk merusak alam yang digunakan untuk memenuhi ambisi dan keserakahannya itu. ${ }^{18}$ Hal serupa dinyatakan oleh Celia Deane-Drummond bahwa kejatuhan manusia ke dalam dosa, menyebabkan terganggunya hubungan antara umat manusia, Allah dan bumi. ${ }^{19}$ Keberdosaan manusia telah menciptakan keterasingan antara manusia dan ciptaan lainnya (Kej.3:14-19;9:1-6). ${ }^{20}$

Tidak dapat disangkal bahwa berbagai kasus lingkungan hidup yang terjadi sekarang ini, baik pada lingkung global maupun lingkup nasional, sebagian besar bersumber dari perilaku manusia. Kasus-kasus pencemaran dan kerusakan, seperti di laut, hutan, atmosfir, air, tanah, dan seterusnya bersumber pada ulah manusia yang tidak bertanggung jawab, tidak peduli dan hanya mementingkan keuntungan diri sendiri. ${ }^{21}$ Ditambahkan oleh Borrong bahwa perilaku pembangunan yang cenderung eksploitatif dan destruktif terhadap sumber daya alam di bumi

\footnotetext{
${ }^{16}$ Yusup Rogo Yuono, "Melawan Etika Lingkungan Antroposentris Melalui Interpretasi Teologi Penciptaan Sebagai Landasan Bagi Pengelolaan-Pelestarian Lingkungan” Fidei: Jurnal Teologi Sistematika dan Praktika, Vol.2, No.1, Juli 2019: 195

${ }^{17}$ Stephen Tong, "Dosa dan Kosmis" Makalah Seminar STEMI tahun 2015 yang disadur ulang dari ceramah Stephen Tong pada acara Laussane di Manila tahun 1989 diakses dari pemuda.stemi.id tanggal 26 September 2019.

${ }^{18}$ Robert P. Borrong, Etika Bumi Baru (Jakarta: BPK Gunung Mulia, 2000), 247-248

${ }^{19}$ Celia Deane Drummond, Teologi \& Ekologi (Jakarta: BPK Gunung Mulia, 1999), 23

${ }^{20}$ Glen H. Stassen, David P.Gushee, Etika Kerajaan (Surabaya: Momentum, 2008), 577

${ }^{21}$ A. Sonny Keraf, Etika Lingkungan Hidup (Jakarta: PT Kompas Media, 2010), 1
} 
karena alam tidak dilihat sebagai suatu sistem kehidupan yang utuh. Lingkungan hidup hanya dilihat dalam konteks ekonomi, khususnya keuntungan materi. Eksploitatif, karena hanya menekankan pertumbuhan sehingga mengeruk sumber daya alam, tetapi kurang memerhatikan keseimbangan ekosistem bumi. Destruktif, sebab dalam proses eksploitasi dan konsumsi manusia cenderung mencemari lingkungan dengan beraneka ragam limbah kimia berupa bahan gas, cair dan padat. Akibatnya, lingkungan hidup terancam parah. Contoh nyata adalah terjadinya perubahan iklim karena pemanasan global. ${ }^{22}$ Aryati Wuryandari menjelaskan bahwa pemanasan global merupakan proses naiknya suhu rata-rata atmosfer, laut serta daratan bumi. Kenaikan suhu bumi ini diakibatkan oleh meningkatnya konsentrasi gas rumah kaca akibat dari ulah manusia sendiri. Akibat pemanasan global banyak sekali kerusakan yang ditimbulkan bisa mencapai seluruh struktur yang berada di bumi ini. Kenaikan suhu secara global akan menimbulkan banyak perubahan seperti halnya menyebabkan cuaca ekstrem dan menaikkan tinggi permukaan air laut, punahnya berbagai macam hewan, berpengaruh terhadap hasil pertanian, hilangnya gletser dan mencairnya es di kutub utara dan selatan. ${ }^{23}$

Kerakusan dan eksploitasi terhadap sumber-sumber daya dalam lingkungan akhirnya menghancurkan lingkungan, dan menyebabkan krisis ekologi. Tindakan korup dan kerakusan manusia (sebagai akibat dosa), maka manusia lebih banyak dikendalikan oleh nafsu dan semangat untuk memeroleh dan memiliki serta mengonsumsi sebanyak mungkin materi, dan pengendalian diri cenderung diabaikan. Sikap hidup seperti ini hanya memikirkan keuntungan ekonomi dengan mengorbankan kepentingan ekologi.

Krisis ekologis yang dihadapi oleh umat manusia dewasa ini berakar dalam sikap manusia yang kurang memperhatikan norma-norma moral dalam hubungan dengan lingkungan hidupnya, bahkan juga dalam hubungan dengan sesamanya. Manusia memandang alam hanya sebagai obyek, yang berguna untuk menjadi alat memenuhi kebutuhan material saja sehingga lingkungan hidup hanya dilihat dalam konteks ekonomi, khususnya keuntungan materi. ${ }^{24}$ Alam dipandang sebagai sarana, tambang kekayaan, sumber energi, sumber kekayaan yang memang harus diekspoitasi bagi kebutuhan manusia. Inilah yang menyebabkan kerusakan krisis lingkungan semakin parah. Manusia kurang menyadari bahwa dengan merusak alam ciptaan, manusia sebenarnya sedang menghancurkan peradaban dirinya sendiri. ${ }^{25}$ Dapat dikatakan bahwa manusia hanya memfokuskan diri pada kesejahteraan dirinya senmdiri dengan memanfaatkan alam sesukanya tanpa memedulikan kelestariannya demi generasi mendatang.

Ilmu pengetahuan dan teknologi tidak dapat dijadikan satu-satunya penyebab adanya krisis ekologis dewasa ini. Namun, kerusakan itu tentu tidak diakibatkan oleh ilmu pengetahuan dan teknologi, tetapi oleh manusia yang telah menciptakan dan yang memperalatnya. Perkembangan ilmu pengetahuan dan teknologi telah disalahgunakan sehingga menjadikan manusia hedonistik dan materialistik. Eksploitasi dan pencemaran

${ }^{22}$ Robert P. Borrong, Etika Bumi Baru (Jakarta: BPK Gunung Mulia, 2000), 281-282

23 Aryati Wuryandari, “Game Interaktif Mencegah Terjadinya Pemanasan Global Untuk Anak” Jurnal SIMETRIS, Vol 7 No 1 April 2016: 311

${ }^{24}$ Robert P. Borrong, 281

${ }^{25}$ Lukas Awi Tristanto, Panggilan Melestarikan Alam Ciptaan (Yogyakarta: Kanisius, 2015), 78 
lingkungan, bukan kemauan ilmu pengetahuan dan teknologi, melainkan kemauan dan kehendak manusia. Jadi, akar dari perbuatan yang mengeksploitasi dan mencemari lingkungan, alam secara berlebihan atau melampaui batas adalah "nir etik"-tidak adanya atau kurangnya norma etis dalam diri manusia. Norma etis di sini adalah norma penghargaan dan norma keadilan serta kasih terhadap lingkungan. ${ }^{26}$ Dengan demikian, dapat dikatakan bahwa krisis ekologis yang dihadapai oleh umat manusia (seluruh bumi) bersumber dalam krisis moral. Misalnya krisis moral di dalam hal mengelola alam dan lingkungan yang telah dipercayakan Tuhan kepada manusia. Akibat krisis moral tersebut, mereka mengeksploitasi dan mencemari alam, lingkungan hidup tanpa rasa bersalah.

Jadi, kita berdosa bukan hanya terhadap Allah yang menjadikan bumi baik sebagai penyataan diri-Nya maupun demi kebaikan kita, melainkan juga berdosa terhadap lingkungan dan diri sendiri serta terhadap orang-orang atau generasi yang akan mendiami bumi di masa mendatang. ${ }^{27}$

\section{Metode Penulisan}

Artikel ini merupakan penelitian kualitatif, yaitu suatu penelitian yang tidak menggunakan populasi, karena penelitian kualitatif berangkat dari kasus tertentu yang ada pada situasi sosial tertentu dan tujuan penelitian kualitatif adalah untuk menghasilkan teori. ${ }^{28}$ Penulis juga menggunakan metode deskriptif, yaitu penelitian yang bermaksud membuat deskripsi mengenai situasi-situasi atau kejadian-kejadian. ${ }^{29}$ Penulis akan mendeskripsikan konsep tentang alam atau lingkungan hidup menurut etika Kristen. Selanjutnya konsepkonsep tersebut dianalisis dengan pendekatan etis-teologis, sehingga diperoleh landasan biblikal untuk bersikap yang tepat terhadap terhadap isu kerusakan alam-lingkungan hidup akibat pengeksploitasian sumber daya alam tanpa tindakan pelestariannya.

\section{Pembahasan}

\section{Pelestarian Alam Sebagai Perwujudan Mandat Pembangunan: Suatu Kajian Etis-Teologis}

Dengan sangat jelas dan tegas dikatakan oleh A. Sonny Keraf di dalam bukunya "Etika Lingkungan Hidup" bahwa masalah lingkungan hidup adalah masalah moral, persoalan perilaku. Lingkungan hidup bukan semata-mata persoalan teknis. Demikian pula, krisis ekologi global yang dihadapi manusia dewasa ini adalah persoalan moral, krisis moral secara global. Karena itu, menurut Keraf diperlukan etika untuk mengatasinya. Lingkungan hidup tidak lagi semata-mata didekati sebagai isu teknis, ekonomi dan politik, melainkan semakin didekati sebagai isu moral atau etis. ${ }^{30}$

Penulis sangat setuju dengan apa yang dikemukan Keraf. Persoalan lingkungan hidup adalah persoalan moral, maka penyelesaiannya tidak bisa hanya didekati secara teknis, melainkan harus didekati secara lebih komprehensif-holistik, termasuk secara etika atau moral tanpa menaifkan pentingnya penyelesaian dan pendekatan teknis. Untuk memahami mengenai pokok persoalan (isu) tentang alam ciptaan menurut perspektif etika Kristen, maka harus mengacu pada Alkitab sebagai

\footnotetext{
${ }^{26}$ Robert P. Borrong, 4

${ }^{27}$ Norman L. Geisler, 396-397

${ }^{28}$ Sugiyono, Metode Penelitian Kuantitatif-Kualitatif dan R\&D (Bandung: Alfabeta, 2011), 216

${ }^{29}$ Sumadi Surya Brata, Metodologi Penelitian (Jakarta: Raja Grafindo Persada, 2002), 18

${ }^{30}$ A. Sonny Keraf, Etika Lingkungan Hidup (Jakarta: PT Kompas Media, 2010), 1
} 
fondasi/pijakan berpikir dan sekaligus bertindak. Berikut ini adalah pandangan etis-teologis mengenai pelestarian alam sebagai perwujudan dari mandat pembangunan atau mandat kultural.

\section{Manusia adalah Penatalayan Alam}

Firman Allah dengan jelas menyatakan bahwa alam semesta memiliki permulaan,'Pada mulanya Allah menciptakan langit dan bumi"(Kej.1:1). Pernyataan atau doktrin penciptaan ini memiliki dua implikasi penting untuk ekologi, yaitu kepemilikan ada pada pihak Allah dan pelanatalayanan ada pada pihak manusia. Allah memilikinya dan manusia memelihara bagiNya.

Celia Deane-Drummond menjelaskan berdasarkan teks Kej.1:27, bahwa hanya manusia yang diciptakan sebagai gambar Allah. Manusia diciptakan sebagai gambar Allah karena peranannya selaku penatalayan atau pelaksana atas ciptaan. Selanjutnya, ia juga menjelaskan di mana gagasan bahwa manusia diciptakan segambar dengan Allah menempatkan manusia dalam suatu hubungan yang unik dengan Allah dibandingkan dengan ciptaan yang lain. Hubungan yang unik itu memberikan tanggung jawab khusus kepada manusia untuk bertindak selaku penatalayanan dan pelaksana harian pemeliharaan ciptaan. Allah memerintahkan manusia menguasai ciptaan dan mengelola bumi. Tugas ini berisi mandat memlihara bumi, bukan mandat mengeksploitasi. Kalau manusia gagal memelihara bumi, maka ia gagal dalam tanggung jawab sebagai penatalayanan ciptaan. ${ }^{31}$

Manusia adalah pengelola atas alam beserta isinya, yaitu untuk menjaga dan bukan sebaliknya mengeksploitasi alam seenaknya. Pemahaman ini sangat penting untuk dimengerti sebagai mandat Tuhan (mandat kultural). Manusia memegang mandat budaya untuk menjaga kelestarian alam. Sebagai orang Kristen, dituntut untuk penggunaan atau pemanfaatan lingkungan fisik dengan penuh penghargaan untuk menjadi penatalayanan yang baik atas apa yang telah Allah berikan. Karena itu, orang Kristen bertanggung jawab terhadap kelestarian alam demi keberlangsungan generasi mendatang.

John Stott menegaskan bahwa "bumi ini kepunyaan Allah maupun manusia". Dikatakan kepunyaan Allah karena Dia yang menciptakannya, dan sekaligus kepunyaan manusia, karena Dia telah memberikan bumi kepada manusia. Menyerahkan di sini, bukan berarti Allah menyerahkan sepenuhnya kepada manusia sehingga Dia tidak mempertahankan hak maupun penguasaan atas bumi lagi, melainkan Dia telah memberikan bumi kepada manusia agar ia memerintah atas nama-Nya. Bumi yang manusia miliki adalah hak pakai, artinya manusia hanya sebagai penyewa atau penggarap, bukan hak milik sebab Allah sendiri tetap sebagai "tuan tanah" (landlord). Jadi, bumi adalah milik Allah dan milik manusia, seperti yang dikatakan oleh Alkitab berikut ini: ${ }^{32}$

Mzm.24:1, Mazmur Daud. Tuhanlah yang empunya bumi serta segala isinya, dan dunia serta yang diam di dalamnya.

Mzm.115:16, Langit itu langit kepunyaan TUHAN, dan bumi itu telah diberikan-Nya kepada anak-anak manusia.

Sebagaimana Geisler katakan bahwa Allah memberi manusia kuasa atas ciptaan-Nya (Kej.1:28), tetapi Dia juga memerintahkan manusia untuk mengusahakan tanah, dan menjaga

\footnotetext{
${ }^{31}$ Celia Deane-Drummond, Teologi \& Ekologi (Jakarta: BPK Gunung Mulia,1999), 21

${ }^{32}$ John Stott, Isu-isu Global (Jakarta: Yayasan Komunikasi Bina Kasih, 2015), 62-163
} 
taman. Ini membutuhkan pengolahan dan perawatan. Bumi adalah taman Allah, dan manusia adalah pengelola taman. ${ }^{33}$

Lagi, Stott menegaskan bahwa kekuasaan manusia atas bumi ini adalah suatu pendelegasian, maka kekuasaan itu perlu dipertanggungjawabkan. Artinya, kekuasaan yang manusia jalankan atas bumi, tidaklah dipahami sebagai hak milik, melainkan sebagai suatu kepercayaan. Manusia bukan pemilik, tetapi pengurus yang mengelola dan mengolahnya atas nama pemilik. Jadi, kekuasaan manusia atas bumi merupakan delegasi dari Allah Sang Pemilik (bumi) dengan maksud agar manusia bekerja sama dengan Dia dan berbagi hasilnya dengan orang lain, maka manusia bertanggung jawab kepada-Nya melalui penatalayanan yang dilakukan. Manusia tidak memiliki kebebasan untuk berbuat sekehendak hatinya atas alam, dan lingkungan hidup. Memang Allah berkata kepada manusia: "Supaya mereka berkuasa ... atas seluruh bumi". Kata "berkuasa atas" tidak sinonim dengan "menguasai" (dengan seenaknya atau keras), apa lagi "menghancurkan". Oleh karena alam, lingkungan hidup telah dipercayakan kepada manusia, ia perlu mengelolanya secara bijak, bertanggungjawab dan tepat serta seproduktif mungkin untuk kepentingan dirinya sendiri dan juga generasi di masa mendatang. ${ }^{34}$

Kemudian Glen H. Stassen dan David P.Gushee menjelaskan yang dimaksud kata "taklukkanlah" yang diperintahkan kepada manusia, adalah menyiratkan tentang keterutamaan manusia, bukan sebagai suatu persetujuan terhada dominasi ke arah eksploitatif atas alam. ${ }^{35}$ Itu sebabnya Celia Deane-Drummond menjelaskan dengan tepat mengenai perintah Allah kepada manusia untuk "menaklukkan" bumi dan "berkuasa" atas semua makhluk hidup. Berdasarkan analisis eksegetis menunjukkan bahwa kata itu hanya menunjukkan "pengusahaan" bumi, bukan dorongan untuk memperlakukan binatang-binatang dengan kasar. Dan bukan juga sebagai surat izin untuk mengeksloitasi bumi bagi keuntungan manusia. Jika tugas "menaklukkan" dan "berkuasa" ditafsirkan keliru menjadi penguasaan/pengeksploitasian, itulah yang menjadi penyebab yang sangat penting di balik krisis ekologis. $^{36}$

Dengan demikian, sebagai penatalayan Allah, hendaknya manusia berkomitmen untuk merawat alam ciptaan-Nya bagi kesejahteraan sesama_-generasi masa mendatang. Kekuasaan yang diberikan Allah kepada manusia adalah kuasa sebagai penatalayan yang bertanggungjawab, termasuk penggunaan atau pemanfaatan sumber daya yang ada. Suatu hal yang mustahil jika Allah menciptakan bumi dan menyerahkan kepada manusia hanya untuk dihancurkan atau dieksploitasi untuk memenuhi kebutuhan sekarang dengan mengorbankan kesejahteraan atau "mengkhianati anak cucu" di masa mendatang. Sebaliknya, kuasa tersebut merupakan pendelegasian atas alam ciptaan, yang di dalamnya memuat unsur pertanggungjawaban baik kepada Allah sebagai Sang Pemilik bumi dan kepada sesama (sebuah kesolidaritasan) serta rasa hormat terhadap lingkungan hidup ciptaan-Nya.

\footnotetext{
${ }^{33}$ Norman L. Geisler, 382

${ }^{34}$ John Stott, 166-168

${ }^{35}$ Glen H. Stassen, David P.Gushee, 578

${ }^{36}$ Celia Deane-Drummond, Teologi \& Ekologi (Jakarta: BPK Gunung Mulia,1999), 19
} 


\section{Pelestarian Alam sebagai Implementasi Kasih kepada Sesama}

Selama ini Gereja lebih banyak memfokuskan pelayanannya pada persoalan yang bersangkut paut dengan pembinaan kerohanian saja, dan masih sedikit terjun kepada bentukbentuk pelayanan yang bersifat komprehensif yaitu mendatangkan shalom secara utuh. Padahal pelayanan Gereja seharusnya juga meneladani pelayanan Kristus, yaitu pelayanan yang merangkumi segi kehidupan manusia secara menyeluruh, baik rohani, jiwani dan jasmaninya.

Mari perhatikan Matius 25:31-46, di mana Kristus mengidentikkan diri-Nya sebagai orang lapar, orang yang sakit, haus, telanjang, terpenjara dan orang asing. Kristus juga menegaskan bahwa apa yang kita perbuat kepada mereka yang membutuhkan uluran tangan kita seperti memberi makan, memberi minum, memberi tumpangan, memberi pakaian, mendoakan dan mengobati, mengunjungi orang dalam penjara, sama seperti melakukannya kepada diri-Nya.

Douma menyatakan bahwa dasar etis orang Kristen adalah berdasarkan perintah rangkap dalam Matius 22:37-39 yaitu kasihilah Allah dan sesamamu manusia seperti dirimu sendiri. Melalui hubungan perseorangan yang rangkap itu semua aspek kehidupan manusiawi diperhatikan: Gereja, perkawinan, keluarga, masyarakat serta perlindungan dan pelestarian alam. Dalam perhatian terhadap tingkah laku (etis) bertanggungjawab terhadap Allah, manusia akan bertemu dengan perintah untuk menguasai dunia ini secara baik (kej.1:28). Dan barangsiapa memikirkan pertanggungjawabannya terhadap sesamanya manusia tidak bisa melupakan lingkungan yang sehat. ${ }^{37}$ Cukup jelas bahwa Allahlah pemilik lingkungan, dan manusia hanya mengusahakannya dengan benar.

Dasar etis dalam Matius 22:37-39 yaitu kasihilah Allah dan sesamamu manusia seperti dirimu sendiri juga mencakup perilaku yang mencerminkan norma keadilan dan kasih (solidaritas) untuk terwujudnya kesejahteraan semua manusia sehingga memerhatikan keseimbangan antara kepentingan manusia masa kini dan manusia di masa depan; antara kepentingan ekonomi dan kepentingan ekologi yang terjalin utuh.

Manusia dan alam merupakan dua hal yang saling terkait dan integral. Manusia tidak diciptakan sebagai makhluk yang independent atau berdiri sendiri dan terpisah dari ciptaanNya yang lain. Manusia dan alam adalah sesama ciptaan. Manusia adalah bagian dari ciptaanNya. Sebelum Allah menciptakan manusia, Ia terlebih dahulu menciptakan alam semesta beserta isinya. Kemudian diciptakanlah manusia itu menurut gambar dan rupa Allah. Manusia diciptakan Allah dari debu tanah dan diperintahkan untuk mengelola alam-Taman Eden untuk kelangsungan hidupnya dan juga keturunannya.

Borrong menjelaskan hubungan antara manusia dan alam. Manusia adalah bagian dari alam, sebab ia diciptakan dari debu tanah (Kej.2:7); dan kalau ia mati, ia akan kembali pada tanah (Mzm.90:3). ${ }^{38}$ Itulah sebabnya manusia harus memperlakukan alam sebagai sesama ciptaan Allah, sekali pun manusia diberi wewenang menaklukkan alam. Maka selain menjaga dan memelihara, manusia harus juga mengembangkan sikap solidaritas terhadap alam.

\footnotetext{
${ }^{37}$ J. Douma, Kelakuan yang Bertanggung Jawab (Jakarta: BPK Gunung Mulia, 2002), 21

${ }^{38}$ Robert P.Borrong, 165
} 
Manusia membutuhkan lingkungan alam yang bersih, segar, dan sehat. Faktanya perkembangan manusia juga sangat dipengaruhi oleh factor lingkungannya. Lingkungan di sini pertama adalah lingkungan social, yaitu interaksi seseorang dengan orang lain yang akan berperan membentuk kepribadian seseorang, dan kedua adalah lingkungan alam (abiotik) seperti air, udara, tanah, tumbuh-tumbuhan, dan sebagainya (termasuk benda-benda mati di sekitarnya).

Untuk mengemban mandat kultural untuk memelihara bumi ini, maka Gereja baik secara institusi maupun perorangan (pada setiap individu) harus bersinergi dengan sesamanya, baik yang seiman maupun nonKristen, melalui institusi pemerintah maupun nonpemerintah dan juga secara perorangan (pada setiap individu), bersama-sama mewujudkan alam, lingkungan hidup yang nyaman, bersih, sehat dan layak untuk ditinggali baik bagi kehidupan masa kini dan juga demi kehidupan generasi di masa mendatang — anak cucu.

Gereja harus mematuhi mandat pembangunan ini. Mandat pembangunan ini dimaksudkan yaitu untuk mengurangi penderitaan masyarakat maupun untuk mengembangkan kehidupan manusia. Dengan kata lain, mandat kultural untuk mewujudkan keadaan sosial yang lebih baik yang terdapat dalam masyarakat. Krisis ekologis sebagai akibat perlakuan buruk manusia terhadap alam seharusnya menyadarkan kita bahwa manusia perlu menata kembali hubungannya dengan sesama ciptaan, yaitu dengan sesama manusia dan lingkungan hidupnya. $^{39}$

Permasalahan lingkungan adalah permasalahan semua orang tanpa kecuali. Sebab itu, Gereja perlu menjalin kerjasama atau berjejaring dengan sesamanya, maupun pemerintah dengan hati tulus untuk mewujudkan shalom di bumi yang kita cintai. Gereja harus berjejaring untuk menyelamatkan lingkungan hidup dari kerusakan. Gereja harus berjejaring dengan lembaga/instansi pemerintah maupun nonpemerintah untuk mengembangkan kesadaran dan tanggung jawab terhadap lingkungan hidup demi terwujudnya kesejahteraan semua makhluk dan seluruh unsur dalam alam, baik untuk kepentingan manusia masa kini dan generasi di masa depan secara berkesinambungan maupun untuk kepentingan alam ini secara keseluruhan sebagai penyangga kehidupan manusia.

Gereja perlu pula menggalang kerja sama dengan pemerintah, organisasi masyarakat swasta dan golongan beragama lain dalam mengkaji, merencanakan dan melaksanakan kegiatan cinta lingkungan secara bersama, baik pada aras nasional maupun regional dan lokal sesuai dengan kebutuhan di daerah masing-masing. Kerja sama ini didasarkan atas kesadaran bahwa persoalan lingkungan bukan masalah kelompok tertentu, melainkan masalah bersama umat Manusia tanpa terkecuali. Bekerjasama untuk mewujudkan kehidupan yang harmonis dan seimbang dengan alam sebagai bagian dari tujuan kehidupan. ${ }^{40}$ Benar, apa yang dikemukakan oleh Rahmat Mulyana, sehubungan dengan penyelesaian masalah dan krisis lingkungan tidak dapat dilakukan secara sepihak, namun diperlukan kerjasama multipihak secara serentak dan melibatkan seluruh lapisan masyarakat. ${ }^{41}$

\footnotetext{
${ }^{39}$ Robert P.Borrong, 285

${ }^{40}$ Robert P.Borrong, 289-290

${ }^{41}$ Rachmat Mulyana,"Penanaman Etika Lingkungan Melalui Sekolah Perduli Dan Berbudaya Lingkungan" Jurnal Tabularasa PPS Unimed, Vol.6 No.2, Desember 2009: 178
} 
Sebagai salah satu wujud implementasi kasih kepada sesama, gereja dapat berpartisipasi baik secara langsung maupun tak langsung. Untuk mengimplementasikan pemeliharaan terhadap alam, Gereja dapat melakukan beberapa tindakan sederhana baik secara langsung maupun tidak langsung. Partisipasi Gereja, secara perseorangan secara langsung, misalnya seperti membuang sampah pada tempatnya, menggunakan air secara efektif, meminimalkan polusi udara, penananam pohon, tidak melakukan penebangan hutan sembarangan, penataan lingkungan hidup yang bersih di sekitarnya, pola hidup hemat (dengan cara mengurangi gaya hidup mewah dan menggantinya dengan gaya hidup berkecukupan atau mengambil secukupnya), kedisiplinan dalam memanfaatkan benda-benda potensial merusak alam/lingkungan baik melalui penggunaan berulang-ulang maupun melalui daur ulang. Selain itu, orangtu haruslah mendidik anak-anaknya agar mereka sayang tanaman/tumbuhtumbuhan, sehingga mereka belajar memelihara dan merawat tanaman/tumbuh-tumbuhan. Dengan demikian, terlatihlah mereka dengan pola hidup yang menghargai alam, lingkungan hidup dan dalam hal bertanggungjawab.

Menurut Borrong, dengan mempraktikkan pola hidup seperti di atas, maka manusia dapat hidup menurut irama daur alam, yakni alam, dimanfaatkan sekaligus dipelihara kelestariannya. Untuk maksud itu, maka manusia harus melakonkan perilaku yang menjaga kelestarian alam bukan saja untuk kepentingan alam melainkan sekaligus untuk kenyaman, kesejahteraan dan kesehatan manusia sehingga kualitas hidup manusia lebih terjamin baik pada masa kini maupun di masa depan. Norma moral seperti ini bisa dikembangkan secara perseorangan maupun kelompok masyarakat, misalnya dalam Gereja. ${ }^{42}$

Sedangkan partisipasi Gereja (lembaga) secara tidak langsung, misalnya, Gereja merencanakan dan mengorganisir program-program yang bersangkut paut dengan kegiatan cinta lingkungan (sesuai dengan kondisi lingkungan masing-masing), seperti gerakan kebersihan, gerakan penghematan, gerakan daur ulang sampah, dan sebagainya. Tujuan gerakan-gerakan ini adalah untuk penyadaran tentang pentingnya kelestarian alam, mengajak umat membudayakan gaya hidup yang ramah terhadap alam, tidak serakah/rakus, materialisme, dsb), dalam menjaga dan mengusahakan keberlangsungan atau kelestarian alam-keharmonisan manusia dengan lingkungan hidupnya.

Untuk itu, Gereja perlu membentuk jaringan kerja sama yang dapat menjadi pelopor dalam memikirkan, merencanakan dan mengorganisasikan program-program yang bersangkut paut dengan kegiatan cinta lingkungan untuk mendorong dan menggerakkan umat agar berperan serta dalam kegiatan mencegah pencemaran dan memulihkan lingkungan yang terlanjur rusak akibat pencemaran. Jaringan kerja ini perlu dibuat agar Gereja-gereja dari berbagai tempat dapat bekerja sama dan saling mengisi dalam meningkatkan berbagai kegiatan mereka sesuai dengan pengalaman masing-masing. ${ }^{43}$

Hasil-hasil dari kegiatan cinta lingkungan tersebut, dapat dipublikasikan melalui buletin gereja atau warta gereja sebagai bentuk kampanye cinta lingkungan sehingga akan terus mendorong umat/warga gereja untuk memberikan kontribusinya supaya shalom Allah terwujud secara konkrit dalam 'koinonia'-kebersamaan umat, kebersamaan dan solidaritas

\footnotetext{
${ }^{42}$ Robert P.Borrong, 286

${ }^{43}$ Robert P.Borrong, 289
} 
(cinta kasih) pada sesama. Bila Gereja ingin melakukan konservasi (pelestarian), maka Gereja juga dapat mengajarkan para anggota Gereja untuk melakukan hal yang sama di rumah.

\section{Kesimpulan}

Untuk memeliharan kelestarian alam-lingkungan hidup sehingga dapat mengatasi atau mencegah krisis ekologi, maka diperlukan perubahan paradigma atau cara pandang dan perilaku manusia terhadap alam secara fundamental. Dibutuhkan sebuah pola hidup atau gaya hidup baru yang tidak hanya menyangkut orang perorang, namun juga budaya masyarakat secara keseluruhan.

Berdasarkan analisis etis-teologis maka dapat disimpulkan, pertama: manusia adalah penatalayan alam. Kelestarian alam, baik air, udara, tanah maupun tumbuh-tumbuhan adalah kebutuhan vital bagi kehidupan manusia dan manusialah yang harus bertanggungjawab mengelolanya secara benar dan bijaksana. Kedua, pelestarian alam sebagai implementasi kasih kepada sesama. Kerusakan alam, lingkungan hidup adalah tanggung jawab semua orang. Semua umat manusia terpanggil untuk memulihkan dan melestarikan alam ciptaanNya, sehingga hubungan keduanya (manusia dan alam) adalah hubungan yang saling menguntungkan. Tidak ada satu orang manusia pun di dunia ini yang dapat "merasa" bebas dari tanggung jawab atas kelestarian alam. Karena itu, Gereja harus turut ambil bagian dalam upaya preventif/pencegahan maupun penanggulangan masalah lingkungan hidup. Pelayanan Gereja tidak boleh dipersempit hanya pada pemenuhan kebutuhan spiritual atau keselamatan jiwa belaka (mandat Penginjilan), tetapi juga mandat kultural atau mandat pembangunan, yaitu kepedulian pada alam, lingkungan hidup sebagai bentuk pengucapan syukur kepada Allah Sang Pencipta, dan sekaligus sebagai implementasi kasih kepada sesama. Itulah sebabnya, orang Kristen bertanggungjawab memelihara dan menjaga dunia alam; menciptakan suatu lingkungan hidup yang bersih dan sehat serta nyaman dihuni untuk kehidupan masa kini dan juga generasi mendatang. Gereja perlu berjejaring dengan berbagai pihak, baik pemerintah maupun non-pemerintah, para tokoh agama, pemuka masyarakat untuk lebih intensif menghimbau dan mengajak kepada para pengusaha dan juga masyarakat untuk bersama-sama lebih mementingkan perhatiannya dalam menjaga dan merawat kelestarian alam dan lingkungan hidup disekitarnya, demi kelangsungan dan kemaslahatan generasi mendatang.

Sehubungan dengan hal tersebut, penanaman kepedulian terhadap kelestarian sumberdaya alam dan lingkungan hidup perlu dilakukan sejak dini agar terbentuk rasa menghargai, memiliki dan memelihara sumberdaya alam sebagai wujud syukur kepada Tuhan, Sang Pemilik dan sekaligus sebagai implementasi kasih kepada sesama.

\section{Referensi}

Borrong, Robert P. Etika Bumi Baru. Jakarta: BPK Gunung Mulia, 2003

Brata, Sumadi Surya. Metodologi Penelitian. Jakarta: Raja Grafindo Persada, 2002

Drummond ,Celia Deane, Teologi \& Ekologi. Jakarta: BPK Gunung Mulia, 1999

Douma, J. Kelakuan yang Bertanggung Jawab. Jakarta: BPK Gunung Mulia, 2002

Geisler, Norman L. Etika Kristen: Pilihan \& Isu. Malang: SAAT, 2010

Keraf, A. Sonny. Etika Lingkungan Hidup. Jakarta: PT Kompas Media, 2010 
Mulyana, Rachmat. "Penanaman Etika Lingkungan Melalui Sekolah Perduli Dan Berbudaya Lingkungan" Jurnal Tabularasa PPS Unimed, Vol.6 No.2, Desember 2009

Meta, Ketut. "Perspektif Historis Dan Perbandingan Pengaturan Masalah Lingkungan Hidup Di Indonesia" Jurnal Cakrawala Hukum, Vol.6, No.1 Juni 2015

Stott, John. Isu-isu Global. Jakarta: Yayasan Komunikasi Bina Kasih, 2015

Stassen, Glen.H dan Gushee, David P. Etika Kerajaan. Surabaya: Momentum, 2008.

Supriatna, Jatna. Melestarikan Alam Indonesia (Jakarta: Yayasan Obor Indonesia, 2008.

Stevanus, Kalis. "Mengimplementasikan Pelayanan Yesus Dalam Konteks Misi Masa Kini Menurut Injil Sinoptik" Fidei: Jurnal Teologi Sistematika dan Praktika, Vol. 1, No.2 Desember 2018

Stevanus, Kalis. Benarkah Injil untuk Semua Orang?. Yogyakarta: Diandra Kreatif, 2017

Stevanus, Kalis. Lihatlah Sang Juruselamat Dunia. Yogyakarta: Diandra Kreatif, 2018

Sugiyono. Metode Penelitian Kuantitatif-Kualitatif dan R\&D. Bandung: Alfabeta, 2011

Siregar, Januari dan Zul, Muaz. "Penegakan Hukum Dalam Tindak Pidana Lingkungan Hidup Di Indonesia", Jurnal Mercatoria Vol. 8 No. 2, Desember 2015

Tjumano, Datauk. "Kerusakan Lingkungan Hidup Di Indonesia" Jurnal Intelijent.Net Verba Volant Scriptta Manent, Juli 2018 https://jurnalintelijen.net/2018/07/03/kerusakanlingkungan-hidup-di-indonesia. Diunduh pada tanggal 26 September 2019

Tristanto, Lukas Awi. Panggilan Melestarikan Alam Ciptaan. Yogyakarta: Kanisius, 2015

Wuryandari, Aryati. "Game Interaktif Mencegah Terjadinya Pemanasan Global Untuk Anak" Jurnal SIMETRIS, Vol 7 No 1 April 2016

Yuono, Yusup Rogo, "Melawan Etika Lingkungan Antroposentris Melalui Interpretasi

Teologi Penciptaan Sebagai Landasan Bagi Pengelolaan-Pelestarian Lingkungan" Fidei: Jurnal Teologi Sistematika dan Praktika, Vol.2, No.1, Juli 2019 